\title{
Pengenalan Injil Dalam Hikmat Allah dan Hikmat Dunia Berdasarkan Teks 1 Korintus 1:18
}

\author{
Mercy Kristini Hia, Hendi \\ Sekolah Tinggi Teologi Soteria Purwokerto \\ mercykristini99@gmail.com
}

\begin{abstract}
The gospel is a message of grace from God for the salvation of mankind. In the gospel, there is also the power to work out salvation in attaining the likeness and image of God. For the gospel to be delivered, humans need to know the word of God written in the gospel. The text of 1 Corinthians 1:18-25 divides knowledge of the gospel into two, namely knowledge of the gospel in the wisdom of God and knowledge of the gospel in the wisdom of the world. Both of these things are correlated with the salvation that will be received by humans. John Chrysostom said that the wisdom of the world to see the life of Jesus Christ and his resurrection is impossible. This conception creates doubt and even distrust of people which leads to the rejection of the gospel. So the denial of the lordship of Jesus Christ is the rejection of the gospel.
\end{abstract}

Keywords: gospel; wisdom; world; destruction

\begin{abstract}
Abstrak
Injil adalah berita anugerah yang berasal dari Allah untuk keselamatan manusia. Di dalam injil juga terdapat kekuatan untuk mengerjakan keselamatan dalam mencapai keserupaan dan segambar dengan Allah. Supaya tujuan injil tersampaikan maka manusia perlu mengenal firman Allah yang tertulis di dalam injil. Teks 1 Korintus 1:18-25 membagi dua pengenalan injil, yaitu pengenalan injil dalam hikmat Allah dan pengenalan injil dalam hikmat dunia. Kedua hal ini korelasi dengan keselamatan yang akan diterima oleh manusia. John Chrysostom mengatakan bahwa hikmat dunia melihat kehidupan Yesus Kristus dan kebangkitannya merupakan sesuatu hal yang mustahil terjadi. Konsepsi ini yang menciptakan keraguan bahkan ketidakpercayaan manusia yang berujung kepada penolakan injil. Jadi penolakan akan ketuhanan Yesus Kristus adalah penolakan terhadap injil.
\end{abstract}

Kata kunci: injil; hikmat; dunia; kebinasaan

\section{Pendahuluan}

Hikmat Allah dan hikmat dunia merupakan dua hal yang berbeda dan dapat menciptakan sebuah hasil yang kontradiksi terhadap pengenalan akan injil. Manusia mendefinisikan hikmat sebagai suatu pengetahuan untuk menilai atau mengenal sesuatu dengan benar. Harls Evan Siahaan menjelaskan hikmat sebagai suatu pengertian atau pemahaman yang dalam mengenai orang, barang, kejadian, atau situasi, yang menghasilkan kemampuan untuk menerapkan persepsi, penilaian dan perbuatan 
(Siahaan, 2016) Hal ini menjelaskan bahwa semua manusia memiliki hikmat, sebab manusia sendiri adalah ciptaan Allah. Sri Wahyudi menuliskan bahwa hikmat dikaruniakan oleh Tuhan, supaya manusia bisa menjalani kehidupan di dunia (Kusradi, 2016) yang artinya tanpa hikmat manusia tidak bisa menjalani kehidupannya. Dalam menjalani kehidupan di dunia manusia selalu diperhadapkan dengan banyak pilihan. Sehingga dengan hikmat dari Allah manusia bisa memilih yang terbaik untuk keselamatan tubuh dan jiwa. Jika hikmat adalah sebuah pengetahuan yang benar untuk menilai sesuatu maka dapat disimpulkan bahwa hikmat dunia akan lebih cenderung menunjukkan kebenaran berdasarkan pandangan dunianya sedangkan hikmat Allah menunjukkan kebenaran Allah. Jadi, bagi umat Kristen hikmat adalah suatu pengetahuan yang benar untuk melihat, menilai, dan melakukan sesuatu sesuai kebenaran yang berasal dari Allah. Persoalannya adalah bahwa hikmat sendiri tidak datang tanpa respon dari manusia itu sendiri. Hal ini dikarenakan manusia selalu memiliki pilihan dan itu berdasar pada kehendak bebas (Susanto, 2017). Kehendak bebas itu melibatkan hati dan juga pikiran.

Hikmat juga digunakan dalam pengenalan akan injil supaya apa yang diajarkan oleh Allah melalui injil bisa dipahami oleh semua orang. Akan tetapi kurangnya kekayaan manusia dalam hal kerohanian menyebabkan hikmat dunia menguasai hati. Sehingga manusia yang dikuasai oleh hikmat dunia dalam pengenalan injil memiliki konsepsi bahwa injil merupakan kebodohan. Timbulnya keraguan dan ketidakpercayaan kepada apa yang tertulis di dalam injil menjadikan manusia menilai injil sebagai teori yang tidak masuk akal. Menolak apa yang diajarkan oleh injil berarti menolak keberadaan Yesus Kristus sebagai Tuhan dan juruselamat. Karena apa yang dituliskan di dalam injil adalah kabar baik keselamatan dari Allah melalui Yesus Kristus.

Seperti halnya beberapa pandangan yang tidak menyetujui keberadaan Tuhan Yesus Kristus sebagai Tuhan. Pertama, pandangan bahwa Yesus Kristus tidak melalui penyaliban. Para penganut pandangan ini percaya bahwa Yudas Iskariot adalah pengganti Yesus Kristus di kayu salib dan menjalani penyaliban. Sehingga pandangan ini tentu saja menolak injil (Lie, 2007). Kedua, pandangan bahwa Yesus tidak mati. Ketiga, pandangan Islam yang mengatakan bahwa Yesus Kristus bukanlah Tuhan melainkan manusia biasa (Sirangki, 2021). Pandangan ini beranggapan bahwa Yesus Kristus diciptakan oleh Allah dengan Firman-Nya tanpa berubah bentuk dan wujud. Sehingga Yesus Kristus tetap menjadi manusia bukan anak Allah. Pandangan-pandangan ini menciptakan keraguan dan hikmat yang logis sehingga terjadinya penolakan akan injil. Sebab di dalam injil, seluruh keallahan Kristus, kematian, dan kebangkitan-Nya disampaikan. Inilah sebabnya pernyataan yang menolak kematian, dan keberadaan Kristus sebagai Tuhan juga berdampak pada injil yang tertolak.

Tujuan dari penulisan artikel ini adalah sebagai berikut: pertama, menemukan konsep pengenalan injil yang benar berdasarkan teks 1 Korintus 1:18. Kedua, untuk menemukan konsepsi hikmat Allah dan hikmat dunia dalam pengenalan akan injil. Ketiga, Untuk memberikan pemahaman bagi pembaca bahwa injil yang dikenal dalam hikmat Allah adalah satu-satunya cara manusia mengenal Allah. Keempat, memberikan sumbangsih bagi semua orang bahwa manusia perlu memiliki dasar yaitu Kristus yang 
adalah hikmat Allah dalam pengenalan injil. Karena Kristuslah yang akan memberitahukan kepada manusia siapa sebenarnya Allah. Sebab, Kristus adalah Firman Allah yang berasal dari Allah (Yohanes 1:1).

\section{Metode}

Dalam penulisan artikel ini, penulis menggunakan beberapa metode sebagai berikut. Pertama, penulis menggunakan metode eksposisi yaitu menguraikan dan memaparkan teks dalam menemukan semantic content di dalam teks tersebut. Kedua, penulis berinteraksi dengan teks-teks lain di dalam Alkitab dan juga komentar bapa-bapa gereja dalam teks tersebut. Ketiga, penulis membuat kesimpulan berdasarkan analis teks yang telah dipaparkan. Pencarian ini bersifat christ centered dan ecclesial. Doktrin ini dipelajari, dipahami, diturunkan ke dalam hati untuk memperbaharui mata hati, jiwa, serta tubuh. Yang akan membuat setiap orang yang melakukannya semakin menguduskan diri dan memiliki ketaatan untuk semakin menjadi serupa dan segambar dengan Kristus.

\section{Hasil dan Pembahsan}

\section{Sintatctic Form}

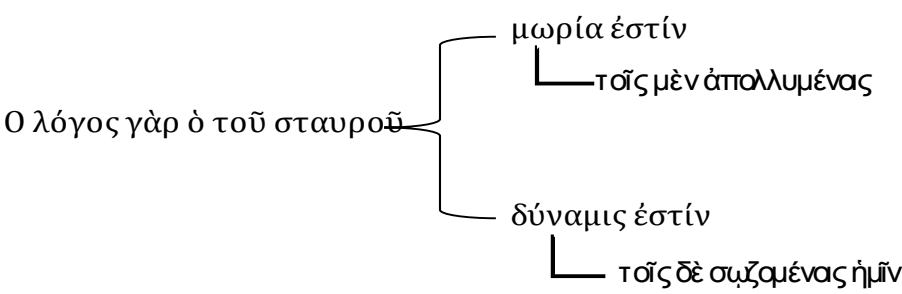

\section{Konteks Historis}

Korintus adalah sebuah kota kuno yang disebut sebagai kota metropolitan di Yunani pada zaman rasul Paulus. Beberapa sumber mengatakan bahwa penduduk kota Korintus adalah orang-orang kaya secara materi tetapi mereka kekurangan dalam pertumbuhan moral yang baik. Kekayaan akan materi ini, membuat mereka lebih angkuh dan tindakan mereka berujung pada dosa. Diantara jemaat Korintus saat itu, ada beberapa orang yang memisahkan diri mereka dari satu kelompok ke kelompok lain berdasarkan pribadi yang mereka kagumi (1 Korintus 1:10-12). Dan hal itu menyebabkan perbedaan pendapat diantara mereka dan menimbulkan perselisihan diantara para jemaat saat itu. Itulah sebabnya dalam surat Paulus yang pertama kepada jemaat Korintus, Paulus menuliskan beberapa nasehat kepada semua jemaat. Nasehat itu ditulis supaya jemaat Korintus membuang semua kebodohan dunia ini dan berlari mencari hikmat yang sesungguhnya.

St. Chrysostom mengatakan bahwa surat Paulus ditulis untuk menjaga dan memelihara persatuan dan persekutuan tanpa ada lagi pertengkaran (Saint Chrysostom, 1889). Tentang masalah ini, Paulus menuliskan di dalam suratnya bahwa dia bukan sosok yang perlu dikagumi seperti halnya orang-orang yang ambisius. Tetapi yang terpenting dalam kehidupan ini adalah mencari Kristus, mengagumi Kristus, dan meneladani Kristus. Paulus adalah hanyalah sebuah alat Tuhan untuk memperkenalkan Kristus sebagai 
juruselamat kepada jemaat Korintus saat itu dan juga untuk seluruh dunia. John Calvin menuliskan bahwa, "Paul, indeed, would have acted with propriety, and in accordance with the nature of his office, though he had baptized ever so many. He rejoices, however, that it had happened otherwise, and acknowledges it as having been so ordered, in the providence of God, that they might not take occasion from that to glory in him, or that he might not bear any resemblance to those ambitious men who endeavored in this way to catch followers" (John Calvin, 1509).

Jemaat Korintus cukup dalam pengetahuan dunia. Beberapa pernyataan menjelaskan bahwa dalam bentuk materi jemaat korintus sangat berkecukupan. Mereka memiliki pengetahuan yang cukup (1 Korintus 1:5) untuk mencari harta dunia. Tetapi moral mereka yang rusak semakin memperjelas bahwa ada sesuatu yang salah di dalam diri atau jiwa mereka. Sehingga untuk mengenal Allah mereka tidak memiliki kemampuan. Sebab mengandalkan akal sendiri dan juga dengan hikmat sendiri, hal-hal tentang Allah tampak bodoh di mata mereka. Mereka hanya mengagumi sesuatu yang bisa mereka lihat dan kebenaran di depan mata jasmani mereka. Sehingga Paulus menegaskan bahwa pemberitaan injil ini, dia lakukan untuk memperkenalkan Kristus sang hikmat itu bukan untuk memperkenalkan dirinya. Hal ini dikatakan supaya jemaat Korintus memahami bahwa yang dicari itu adalah isi dari apa yang disampaikan bukan pribadi yang menjelaskan. Karena Paulus hanyalah alat Tuhan untuk menyampaikan Firman-Nya.

\section{Pembahasan}

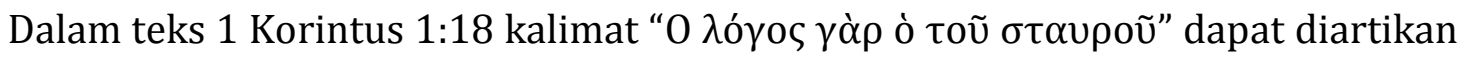

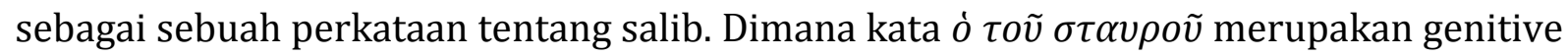

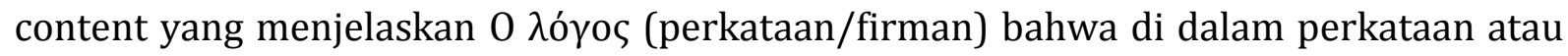
firman itu berisi tentang peristiwa salib. Ungkapan kata "firman/perkataan" yang tertulis

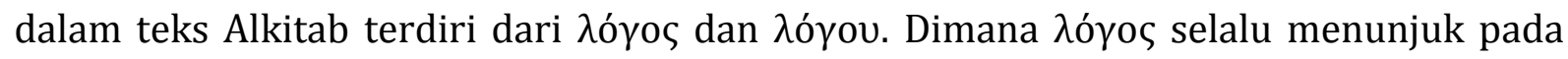
nominative case (Matius 28:15; Lukas 4:32; Yohanes 1:14; Yohanes 10:35), sedangkan

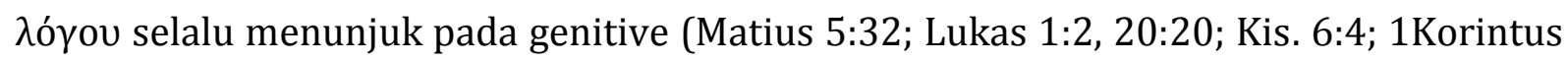

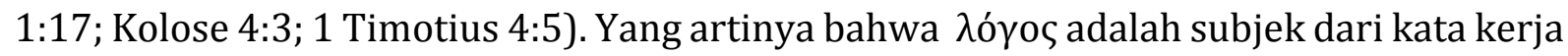

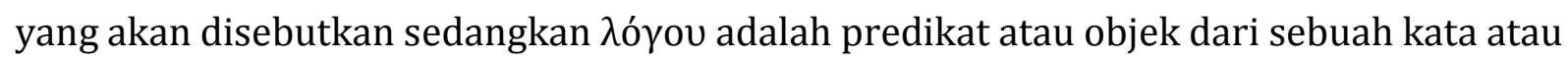
kalimat yang berkedudukan sebagai subjek. Paulus dengan sengaja menggunakan kata

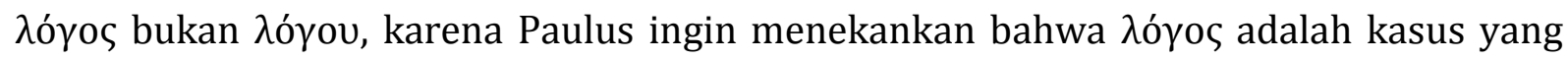
penting dalam sebuah kalimat tersebut. Sehingga dapat diartikan tanpa $\lambda o ́ \gamma o \varsigma$ (Firman) kalimat berikutnya tidak dapat dimengerti. Jadi, dalam konteks surat 1 Korintus 1:18

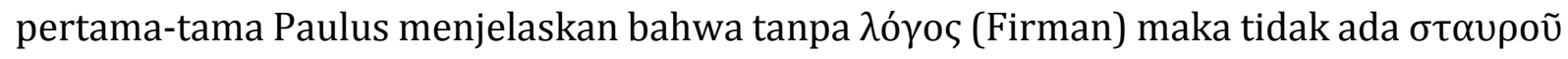
(salib). Firman yang berisi tentang Salib ini adalah sebuah peristiwa penting. Dan Firman itu adalah injil yang menjadi subjek dari kemenangan Kristus juga di kayu salib.

Peristiwa Salib adalah sebuah bukti dari kemenangan Kristus dari iblis, dosa, dan kematian. Menurut Ware, "Dengan sendirinya, kematian Kristus di kayu salib adalah kemenangan (Kalistos ware, 1997). Dengan darah salib Kristus, Tuhan memperdamaikan diri-Nya dengan semua manusia yang berdosa. Sehingga sekarang, manusia sudah memiliki hubungan dengan Allah (Kolose 1:20;2 Korintus 5:18) itulah kemenangan. 
Karena kapan pun Anda membaca injil, Anda sedang berkomunikasi dengan Allah (BELIEFS_of_Orthodox_Christians.Pdf, n.d.). Karena injil itu sendiri adalah Firman yang merupakan subjek dari kemenangan atas dosa, iblis, dan kematian. Kemenangan Kristus di atas kayu salib karena kasih-Nya yang begitu besar mengalahkan iblis, dosa, dan kematian. Sehingga, perseteruan telah lenyap oleh karena salib itu dan sekarang setiap orang yang percaya telah disatukan dalam satu tubuh (Efesus 2:16). Dan peristiwa ini adalah kabar baik bagi semua manusia yang percaya kepada-Nya. Itulah sebabnya perkataan tentang salib ini disebut sebagai injil. Jadi, peristiwa salib yang dikatakan dalam surat 1 Korintus 1:18 adalah injil yang berisi tentang kemenangan Kristus di atas kayu salib dalam hal mengalahkan dosa, iblis, dan maut (Kolose 1:20; Filipi 3:18).

Peristiwa kematian Kristus berdampak bagi manusia yang terikat dosa. Manusia yang dulunya terikat dan berada dibawah perbudakan dosa, ikut menang dan bebas dari belenggu dosa, oleh karena kemenangan Kristus. Dan itu adalah anugerah keselamatan bagi semua orang. Karena injil berisi tentang kesaksian penebusan yang berkelanjutan (Fr. Trados Y. Malaty, 1993). Dimana kemenangan Kristus di atas kayu salib yang dikatakan di dalam injil adalah kemenangan bagi semua orang yang menerima injil itu. Injil juga merupakan ajaran turun temurun yang diajarkan oleh para rasul tentang Yesus Kristus (lihat, Irenaeus of Lyons, 202), karena perkataan salib ini berisi tentang kebenaran, keselamatan bagi orang-orang yang percaya kepada Yesus Kristus maka harus disampaikan kepada semua orang dari generasi-kegenerasi. Artinya keselamatan itu berlaku bagi semua orang dari zaman ke zaman juga. Jadi, semua orang memiliki kesempatan untuk menerima keselamatan dan kemenangan dari Yesus Kristus.

Paulus menggambarkan bahwa perkataan salib bagi jemaat Korintus adalah sebuah hal yang sangat penting untuk dipahami oleh gereja pada saat itu. Gereja perlu mengetahui bahwa injil itu, bukan sebuah kelemahan, bukan tuntutan yang membuat gereja menderita tapi seharusnya, perkataan tentang salib itu adalah sebuah kekuatan yang luar biasa atau kuasa yang sangat kuat yang berasal dari Allah. Karena injil itu juga berisi energy yang menyelamatkan dan menghidupkan. Seperti yang dikatakan oleh Hendi bahwa, Injil adalah kuasa Allah yaitu energi Allah yang kita sebut sebagai anugerah atau kasih karunia Allah. Injil adalah kasih karunia Allah yang menyelamatkan karena ada energi atau kuasa Allah yang menghidupkan roh kita yang telah mati sehingga kita dilahirkan baru secara roh menempati kemanusiaan baru (Hendi, 2018). Selain itu injil juga berisi segala sesuatu yang dikehendaki dan dilakukan oleh Allah. Sehingga ini membantu orang Kristen untuk mengenal Allah. Dengan injil manusia bisa meyakini Kristus yang hidup dan memilikinya di dalam hatinya (Manafe, 2016). Seperti yang dikatakan oleh Kallistos Ware, bahwa segala sesuatu di dalam injil yang berisi tentang Kristus yang diucapkan, dilakukan, diderita oleh Kristus adalah berasal dari satu subjek pribadi yang sama yaitu Anak Allah yang kekal (Kalistos ware, 1997). Akan tetapi, pada kenyataannya perkataan yang berisi tentang salib ini tidak dianggap sebagai kabar baik oleh sebagian orang. Peristiwa ini jika dibiarkan, maka ada banyak orang yang akan menghilangkan keselamatan personal untuk dirinya hanya karena penolakan akan injil keselamatan itu. 
Berdasarkan pemaparan di atas, dapat disimpulkan bahwa injil adalah unsur terpenting dalam kehidupan manusia. Sebab injil berisi hidup yang mengajarkan kehidupan kekal bagi semua manusia. Perkataan tentang salib yang disebutkan dalam 1 Korintus 1:18 adalah injil yang berasal dari Allah yang berisi tentang kemenangan Kristus atas dosa, iblis, dan kematian, yang disampaikan kepada semua manusia. Dimana semua orang percaya ikut menang oleh karena Kristus. Melalui injil manusia bisa mengenal Allah di dalam pribadi Kristus. Sebab, Kematian Kristus yang benar adalah inti dari injil itu sendiri (Hendi, 2018). Kabar baik ini disebut sebagai injil bagi semua orang yang percaya kepada Yesus Kristus (Roma 1:16). Injil menciptakan sebuah pandangan yang berbeda bagi setiap orang. Karena injil, memberikan pandangan tentang penderitaan Kristus di taman Getsemani dan semua peristiwa di dalamnya dan kemudian menjanjikan keselamatan bagi semua orang. Dan hal-hal ini merupakan sebuah pertentangan bagi orang-orang tertentu (Ware, 1997), yang tidak memiliki hikmat. Tapi bagi mereka yang memiliki hikmat Allah injil adalah asupan, makanan, minuman, gizi, vitamin yang akan memberi kekuatan dalam mengerjakan keselamatan. Melalui injil, semua orang-orang yang percaya bisa melihat Kritus yang digambarkan di dalam injil. Mulai dari kehidupan nyata-Nya, pekerjaan yang dilakukan-Nya baik di dunia maupun cerita-Nya tentang kerajaan surga bagi dunia dan orang-orang percaya. Dan melalui injil juga menciptakan pengertian dan pemahaman akan kehendak Allah kepada seluruh umat ciptaan-Nya.

Melihat injil dalam hikmat dunia menciptakan pandangan yang kontra terhadap terhadap pengenalan Allah. Dari pandangan hikmat dunia injil adalah sebuah kabar yang membinasakan. Kata $\mu \omega \rho$ í $\alpha$ yang terdapat di dalam 1 Korintus 1:18 diartikan sebagai sesuatu yang tidak bisa memahami hal-hal rohani (1 Korintus 2:14), dan kebodohan bagi Allah yaitu hikmat yang berasal dari dunia (1 Korintus 3:19). Sedangkan óno $\lambda \lambda u \mu \varepsilon ́ v o เ \varsigma$ merupakan kata passive yang bersifat present dan diartikan sebagai binasa (2 Tesalonika

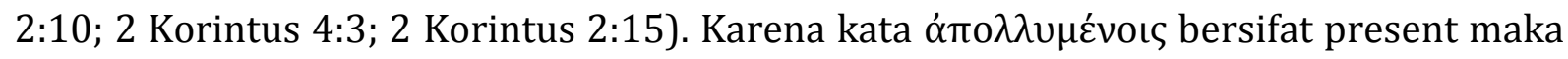
bisa diartikan bahwa kebinasaan yang dimaksud adalah kebinasaan masa itu yang sedang berlangsung dan akan datang. Berarti dalam pandangan orang yang tidak memiliki hikmat Allah, injil adalah sesuatu yang membinasakan mereka pada masa itu di dunia ini. Seperti yang dikatakan Paulus dalam suratnya kepada jemaat Korintus bahwa seseorang tidak bisa memahami perkataan dari Allah terjadi karena pikiran mereka yang mengeras $\dot{\varepsilon} \pi \omega \rho \omega \dot{\theta \eta}$ (2 Korintus 3:14) dan hati mereka yang memiliki penutup (2 Korintus 3:15). Hal yang sama juga dikatakan oleh Ambrosiaster bahwa "Injil keselamatan yang dianugerahkan oleh salib tampak seperti kebodohan dan kebinasaan dimata orang sesat."(Ambrosiater, n.d.)

Orang-orang yang tidak bisa menerima injil ini adalah mereka yang tidak memiliki kemampuan untuk mengenali sesuatu yang bersifat rohani yang berasal dari Allah. Manusia yang tidak bisa menerima injil juga disebut sebagai manusia yang tidak menerima dan mengasihi kebenaran yang sebenarnya menyelamatkan mereka (2 Tesalonika 2:10). Dan mereka yang tidak menerima injil tentang kemenangan Kristus ini disebut sebagai penghina-penghina yang harus dilenyapkan (Kisah Para Rasul 13:41). Sebab mereka tidak menerima kabar baik tentang kematian, penguburan, dan 
kebangkitan Yesus Kristus. Itulah sebabnya mereka lenyap karena diri mereka sendiri. Mengapa sebagian orang tidak menerima perkataan yang berisi tentang salib ini? Karena mereka memakai hikmat dunia (1 Korintus 3:19) bukan hikmat dari Allah. Selain itu, manusia yang menggunakan hikmat dunia adalah manusia yang dianggap bodoh oleh Allah (1 Korintus 1:20). Hal ini artinya manusia yang memiliki hikmat dari dunia saja adalah orang-orang yang mengangap bahwa injil adalah sebuah kehancuran bagi mereka.

Hal ini adalah sebuah peristiwa pertentangan yang terjadi di dalam hati. Antara hati yang bisa menerima Allah dan hati menolak Allah. Hati yang memandang kabar baik ini kehancuran (1 Korintus 1:18a) merupakan hati yang masih memiliki manusia duniawi/hati yang berasal dari daging karena manusia duniawi yang menempati hati itu tidak bisa menerima apa yang berasal dari Roh Allah (1 Korintus 2:14). Karena itu hati ini tidak punya kemampuan untuk memahami sesuatu yang berasal dari Allah. Kemungkinan besar jiwa atau hati yang tidak bisa menerima kekuatan Allah ini adalah jiwa yang mengalami masalah. Seperti yang dikatakan John Chrysostom, bahwa hati terkadang mengalami masalah yang tidak disadari sehingga menyebabkan jiwa kita itu binasa (Chrysostom, n.d.). Oleh karena itu, hati atau perangkat batin terus-menerus berjaga-jaga dan dalam keadaan sadar. Hati juga perlu terus di perbaiki, supaya mempunyai kemampuan untuk menilai apa yang berasal dari Allah dan apa yang berasal dari dunia, sehingga mereka tidak menjadi manusia yang bodoh, yang tidak memiliki hikmat, yang memandang firman Allah adalah sebuah kabar yang menghancurkan. Tetapi, mereka akan memandang injil sebagai keselamatan yang mendatangkan kekuatan dalam diri setiap orang percaya.

Bagi mereka yang hatinya diisi dengan hal-hal dunia, pemberitaan injil ini adalah sesuatu yang membinasakan mereka. Pandangan mereka kabur, mata hati mereka tertutup karena tidak memiliki hikmat dari Allah. Sehingga mereka memandang sesuatu hal yang baik itu justru membawa malapetaka. Atau kebinasaan dalam hidup. Begitu juga sebaliknya bahwa hal yang membawa malapetaka justru hal baik bagi mereka. Jadi, seharusnya mata hati yang rusak itu dibuka supaya bisa diperbaiki, diperbaiki supaya bisa menerima hikmat dari Allah, kemudian bisa mengenal kebenaran yang akan mendatangkan kekuatan yang berasal dari Allah. Sebab manusia yang memiliki hikmat dari Allah yaitu mereka yang memiliki hati yang mengerti, memahami, dan melakukan apa yang berasal dari Allah. Tetapi hikmat yang berasal dari dunia menolak apa yang berasal dari Allah (1 Korintus 3:19). Hikmat yang berasal dari Allah itu adalah Firman itu sendiri (Kolose 2:3) (Hendi, 2019). Firman itu sendiri adalah Pribadi Yesus Kristus (Yohanes 1:1;14). Jadi, hikmat Allah adalah pribadi Kristus itu sendiri. Injil adalah kekuatan bagi semua orang yang menempatkan Kristus di dalam pikiran, hati, dan kehidupan mereka.

Kekuatan yang berasal dari Allah yang tidak hanya menyelamatkan jiwa namun, mampu menyelamatkan tubuh dari kematian kekal. Kekuatan ini memberikan pertahanan yang kekal sebab ia berasal dari Allah yang kekal. Oleh sebab itu, dapat

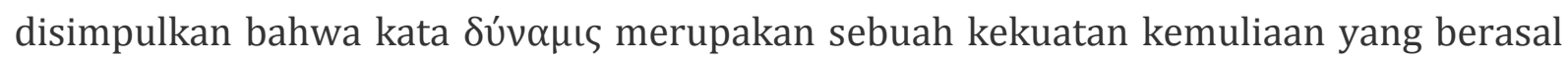
dari Allah yang menyembuhkan dan menyelamatkan setiap orang yang percaya kepada- 
Nya. Sedangkan kata $\sigma \omega \zeta o \mu \varepsilon ́ v o ı \varsigma ~ m e n u n j u k k a n$ pada kata yang bersifat dative. Dimana dative adalah penerima objek tidak langsung (Syafaat, n.d.). Sedangkan objek langsung

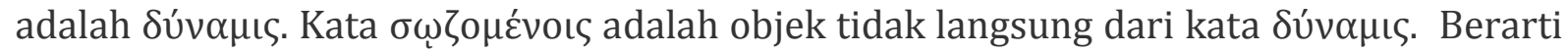
objek yang menerima kekuatan itu adalah orang yang memiliki keselamatan itu. Sebab di dalam injil ada kekuatan ilahi yang memimpin kepada keselamatan (Gea, 2018). Orang yang selamat adalah mereka yang menempatkan Kristus di dalam hati, pikiran, dan kehidupannya. Mereka yang memiliki kekuatan dari Allah adalah manusia yang memiliki hikmat Allah di dalam hatinya. Dan orang yang memiliki hikmat Allah di dalam hatinya adalah dia yang mengenal Allah (Matius 7:21-23). Karena sesungguhnya hikmat berasal dari Tuhan (Amsal 2:6). Dan mengenal hikmat adalah mengenal Kristus terlebih dahulu karena Dialah hikmat itu, dialah yang memiliki hikmat itu (Amsal 3:19; Lukas 2:40).

\section{Kesimpulan}

Hikmat Allah melihat injil sebagai kekuatan yang melaluinya setiap orang mengenal Allah dan mengenal keselamatan sebagai anugerah Allah. Sedangkan injil dalam konsep hikmat dunia merupakan teori yang bodoh yang membawa kebinasaan. Sebagai alasan bahwa dalam proses menuju serupa dengan Kristus manusia perlu mengerjakan keselamatan individu. Hikmat Allah membantu manusia untuk memahami semua tentang Allah dan tujuan hidup yang sebenarnya. Dunia dalam pengetahuannya menilai injil sebagai sesuatu yang bodoh dan tidak sesuai dengan logika manusia. Sebab manusia mengandalkan kemampuan intuisi dan fakta di depan mata yang sebenarnya tidak mampu digunakan untuk pengenalan akan Allah. Penelitian analisis data dan penjelasan semantis data telah membuktikan bahwa hikmat dunia tidak bisa dijadikan dasar pengenalan Allah di dalam injil. Teks 1 Korintus 1:18-25 memberikan penjelasan tanpa hikmat Allah adanya injil bisa membinasakan manusia. Bukan manusia yang dijadikan binasa karena injil tapi manusia menjadi binasa karena bersama dengan hikmat dunia yang telah binasa.

Manusia berdosa yang dulunya telah terputus hubungan dengan Allah dijadikan selamat oleh karena Kristus yang disampaikan di dalam injil. Karena manusia berdosa yang menerima injil dan percaya pada Yesus Kristus sebagai juruselamat memperoleh penyatuan dengan kematian, penguburan, dan kebangkitan Yesus Kristus. Untuk meperoleh pengenalan akan Allah, manusia harus kembali kepada Allah. Dalam proses kembali kepada Allah manusia membutuhkan injil dan pengenalan Allah di dalamnya. Pengenalan akan injil juga harus didasarkan oleh hikmat Allah. Supaya apa yang disampaikan di dalam injil dapat dipahami dan dilakukan dalam kehidupan sehari-hari. Sikap manusia terhadap injil inilah yang akan menentukan manusia itu selamat atau binasa. Jadi, aksi yang akan diambil oleh manusia menentukan manusia memiliki keselamatan kekal bersama Allah atau kebinasaan kekal bersama dunia yang telah binasa. 


\section{Rujukan}

Ambrosiater. (n.d.). Catena Bible: Commentaries.

BELIEFS_of_Orthodox_Christians.pdf. (n.d.).

Chrysostom, J. (n.d.). A Selct Library Of The Nicene And Post-Nicene Fathers of the

Christian Chruch: Homilies on the Epistles of Paul Tto the Corinthians. XIICT\&t

Clark), 17.

Fr. Trados Y. Malaty. (1993). The Apostolic Fathers. St. George's Coptic Orthodox Chruch, 15.

Gea, I. (2018). Beritakan Injil Kepada Segala Makhluk. BIA': Jurnal Teologi Dan

Pendidikan Kristen Kontekstual, 1(1), 56-69. https://doi.org/10.34307/b.v1i1.19

Hendi. (2018). Buku Inspirasi Kalbu II (2018). 22.

Hendi. (2019). inspirasi kalbu 3. I. Maisa S, Ant, 48.

John Calvin. (1509). Commentaries On The Epistles Of Paul The Apostle To The Corinthians. I(Grand Rapids, MI: Christian Classic Ethereal Library), 52.

Kalistos ware. (1997). The Orthodox Way. Crestwood: St. Vladimir's Seminary Press, 107.

Kusradi, S. W. (2016). LEBIH BAIK HIKMAT DARI PADA KEPERKASAAN (Suatu Study Eksegetis Pengkhotbah 9: 13-18 Dan Relevansinya Bagi Para Pemimpin Kristen). SCRIPTA: Jurnal Teologi Dan Pelayanan Kontekstual, 1(1), 64-83. https://doi.org/10.47154/scripta.v1i1.29

Lie, B. (2007). Benarkah Yesus Tidak Mati Disalib? : Sebuah Pertanggungjawaban Iman terhadap Pandangan Islam. Veritas: Jurnal Teologi Dan Pelayanan, 8(1), 83-96. https://doi.org/10.36421/veritas.v8i1.170

Manafe, Y. Y. (2016). Makna Unkapan “Jangan Hidup Lagi Sama Seperti Orang-Orang Yang Tdak Mengenal Allah Dengan Pikirannya Yang Sia-Sia” Menurut Efesus 4:17. SCRIPTA: Jurnal Teologi Dan Pelayanan Kontekstual, 2(2), 21-36.

https://doi.org/10.47154/scripta.v2i2.18

Saint Chrysostom. (1889). Homilies On The Epistles Of Paul To The Corinthians. 3.

Siahaan, H. E. R. (2016). Hikmat Sebagai Implikasi Pendidikan Kristiani: Refleksi 1 Rajaraja 3:1-15. DUNAMIS: Jurnal Penelitian Teologi Dan Pendidikan Kristiani, 1(1), 15. https://doi.org/10.30648/dun.v1i1.99

Sirangki, H. (2021). Makalah Yesus Logos telaah terhadap Perspektif Yohanes VS Islam.

Susanto, Y. N. (2017). Pandangan Teologis Tentang Kehendak Bebas Manusia dan Relevansinya dengan kehidupan Orang Percaya Saat Ini. Journal of Chemical Information and Modeling, 53(9), 1689-1699.

Syafaat. (n.d.). Perbedaan Accusative dan Dative Case Dalam Grammar Bahasa Inggris". 